[Araştırma Makalesi / Research Article ]

\section{Kastamonu Eğitim Dergisi Kastamonu Education Journal}

Eylül 2019 Cilt:27 Sayı:5

kefdergi.kastamonu.edu.tr
Başvuru Tarihi/Received: 16.08 .2018

Kabul Tarihi/Accepted: 12.12 .2018

DOI: $10.24106 /$ kefdergi.3291

\title{
Pedagojik Formasyon Sertifika Programına Katılan Coğrafya Bölümü Öğrencilerinin Özel Öğretim Yöntemleri Dersine İlişkin Görüşleri'
}

\section{Opinions of Geography Department Students' Participating in Pedagogical Formation Certificate Program on Special Teaching Methods Course}

\section{Öz}

\author{
Fatih AYDIN², Ali Çağatay KILINÇ3
}

Bu çalışmanın amacı, pedagojik formasyon eğitimi alan coğrafya bölümü öğrencilerinin Özel Öğretim Yöntemleri Dersine (ÖÖYD) ilişkin görüşlerini belirlemek ve bu dersin etkililiğinin artırılması için öneriler ortaya koymaktı. ÇaIışma nitel araştırma yöntemi ve tipik durum çalışması olarak desenlenmiştir. Araştırmaya 2016-2017 güz yarıyılında Karabük Üniversitesinde öğrenim gören ve pedagojik formasyon sertifika programı kapsamında ÖÖYD alan toplam 122 coğrafya bölümü öğrencisi katılmıştr. Çalışmada yedi sorudan oluşan yarı yapılandırılmış bir görüşme formu kullanılarak veriler toplanmıştır. Araştırma sonucunda elde edilen bulgular şunlardır: Coğrafya bölümü öğrencilerinin çoğunluğu, ÖÖYD'den edindikleri bilgi ve becerilerin öğretmenlik yaşamlarına katkı sağlayacağını düşünmektedir. Katılımcıların çoğunluğu ders süresinin yetersiz olduğunu ifade etmiştir. Çalışmaya katılan öğrenciler bu ders kapsamında uygulama saatlerinin artrılması gerektiğini ve sınıf içinde daha fazla uygulama yapmak istediklerini ancak ders saatinin yetersiz olduğunu belirtmişlerdir. Katılımcılar bu ders sürecinde yöntem ve tekniklerin coğrafya derslerinde nasıl kullanılacağı üzerinde daha fazla durulması gerektiğini ifade etmişlerdir. Öğrencilerin önemli bir bölümü bu dersi almadan önce bir beklentilerinin ve bir fikirlerinin olmadığını ancak bu dersi aldıktan sonra coğrafya dersinin sınıfta ve sınıf dışı öğrenme ortamlarında daha zevkli hale nasıl getirilebileceğini öğrendiklerini ve bu dersin beklentilerini karşıladığını belirtmişlerdir. Etkili bir coğrafya öğretiminin sağlanması için ÖÖYD’nin geliştirilmesi gereken yönlerine ilişkin coğrafya bölümü öğrencileri süre ve uygulamanın artırılması gerektiğini ön plana çıkarmışlardır.

Anahtar Kelimeler: öğretmen eğitimi, özel öğretim yöntemleri, pedagojik formasyon

\section{Abstract}

The purpose of this study is to determine the opinions of the Geography Department students about the "Special Teaching Methods Course (STMC) and to propose suggestions for increasing the effectiveness of this course. This qualitative study was designed as a typical case study. A total of 122 students from the geography department who participated in Pedagogical Formation Certificate Program at Karabuk University and taking STMC constituted the participants of the study. A semi-structured interview form including seven questions was used to collect the data of the study. The results were as follows: Most of the students of the Geography department participating in Pedagogical Formation Certificate Program thought that the knowledge and skills obtained from this course would contribute well to their teaching lives. Most of the participants stated that the time allocated for the course was limited. Most of the students participating in the current study articulated that the practice hours within this course should be increased and that they would like to practice more, however, the duration of the course was not enough for this. Participants also emphasized that this course should focus more on how to use various methods and techniques in Geography courses. Most of the students stressed that they had no ideas or expectations before taking this course, however, they learned how to make geography courses more enjoyable in out-of-classroom and in-classroom environments and that their expectation became real. Participants stated that the duration of the STMC and the time allocated for the practice within this course should be increased in order to ensure more effective geography teaching.

Keywords: teacher education, special teaching methods, pedagogical formation

1 Bu araştırma Uluslararası Sosyal Bilgiler Eğitimi Sempozyumunda- VI (04-06 Mayıs 2017/ Eskişehir) sözlü bildiri olarak sunulmuştur.

2 Karabük Üniversitesi, Edebiyat Fakültesi, Coğrafya Bölümü, Karabük, Türkiye; https://orcid.org/0000-0002-8940-5332

3 Karabük Üniversitesi, Edebiyat Fakültesi, Eğitim Bilimleri Bölümü, Karabük, Türkiye; https://orcid.org/0000-0001-9472-578X

Atıf / Citation: Aydın, F., \& Kılınç, A. Ç. (2019). Pedagojik formasyon sertifika programına katılan coğrafya bölümü öğrencilerinin özel öğretim yöntemleri dersine ilişkin görüşleri. Kastamonu Education Journal, 27(5), 2067-2076. doi:10.24106/kefdergi.3291 


\section{Extended Abstract}

Introduction: Although there are studies on the effects of teaching methods in the field of geography on the attitudes, achievements, and motivations of the students, the lack of studies on Special Teaching Methods Course (STMC) is one of the reasons why such study is important. The purpose of this study is to determine the opinions of the Geography Department students about the STMC to propose suggestions for increasing the effectiveness of this course. Within the framework of this main purpose, the following questions were asked:

What are the contributions of the STMC to the professional life of the teacher candidates?

What is the importance of STMC in terms of Geography teaching?

What are students' opinions on the time allocated for theory and practice?

What were students' expectations before taking STMC?

What can be done to increase the effectiveness of the STMC?

Method: A typical case study under qualitative research method was used in this study to determine the opinions of students of the Geography department who were trained in the pedagogical formation certificate program with respect to STMC. A total of 122 the geography department students participating in Pedagogical Formation Certificate Program at Karabuk University constituted the population of the study. A semi-structured interview form was used to collect the data of the study. The data were analyzed by content analysis.

Conclusion and Discussion : One of the prominent results of this research, which investigated the views of students of Geography department who received pedagogical formation education is that most of the students participating in the current study stated that the knowledge and skills gained from STMC contributed well to the students' teaching career. In addition, teacher candidates stated that this course had an important place in Geography teaching. Participants stated that they learned important things within the scope of this course with respect to teaching geography lessons more accurately and effectively and to being an effective teacher. In a study conducted on mathematics teacher candidates, Eraslan (2009) emphasized that STMC is facilitating their professional lives. Gürbüztürk and Koç (2016) have also indicated that the STMC has given them the skills both to use teaching information, methods and techniques effectively.

As a result of the study, Geography department students stated that the theory dimension is sufficient in STMC, however, the practice dimension should be emphasized more so that this course can be carried out more effectively and appropriately. The findings of a study conducted on Turkish teacher candidates by Akyüz, Özcan ve Altiparmak (2015) supports the results of this research. The suggestion of increasing the number of practices done in the course is in line with the results of the research conducted by Akpınar, Çolak, and Yiğit (2012) with regard to STMC.

In this study, the students expressed the points which should be focused more and stated how to use effective teaching methods and techniques in Geography lesson. According to this, the students in the geography department see STMC as a lesson which contributes to the effective presentation of the field knowledge. It is therefore expected that the teacher candidates should benefit from this course in terms of the principles, methods, and techniques related to the teaching of the relevant lessons. For this reason, teachers should be equipped with the knowledge, skills, and traits of how to apply explanations, teaching strategies, methods and techniques related to classroom practices rather than theoretical knowledge (Calp, 2005: 15).

Depending on the findings from the current study, the following suggestions can be presented:

According to the opinions of participants, the instructors who teach these courses should inform the students about the content at the beginning of the lesson and increase their readiness towards the course.

Teacher candidates who participated in the present study stated that more emphasis should be put on classroom management within the scope of this course. Class management refers to the provision and maintenance of a suitable environment for learning. To provide this, the teacher needs to plan in-class activities and learning-teaching processes effectively. When planning activities in the scope of STMC, classroom management strategies should be taken into consideration such as attracting students' attention in the course, increasing motivation, increasing class participation and using healthy communication channels in class. At the same time, geography teacher candidates should use effective classroom management strategies in practice schools where they practice internship within the school experience course.

The theory and practice dimensions of the STMC should be reorganized and the time allocated for practice should be increased. 


\section{Giriş}

ÖÖYD öğretmen adaylarının alanlarında kullanacakları öğretim programları, öğretim sürecine yönelik bilgi ve becerileri, alana özgü strateji, yöntem, teknik, materyal ve araç-gereç bilgilerini içermektedir (Çeliköz, 2016; Gürbüztürk ve Koç, 2016). ÖÖYD'de öğretmen adaylarına mesleklerine başlamadan önce hangi sorunlarla karşılaşabilecekleri ve neyi nasıl değerlendirebilecekleri aktarılmaya çalışııır (Görgen, Çokçalışkan ve Korkut, 2012). ÖÖYD, öğretmen adaylarına temel mesleki yeterlilikleri kazandırıldığı ve öğretmenlik mesleğine ilişkin genel bilgiler ile alan bilgisini oluşturan bileşenlerin alanın öğretimini sağlayacak biçimde dönüştürüldüğg̈ bir süreçtir (Gülçiçek, 2018). Başka bir anlatımla, öğretmen adayına yalnızca öğretime ilişkin genel bir bakış açısı kazandırmayı değil, ona meslekte karşılaşacağı tüm durumlara ilişkin bakış açısı ve deneyim edindirmeyi amaçlar.

Öğretmen yetiştirme sürecinde önemli bir yere sahip olan ÖÖYD ile öğretmen adayları için gerekli olan mesleki bilgi ve yeterliliklerin öğretmen adaylarına kazandırılması amaçlanmaktadır. Öğretmen adayları, bu ders aracılığıyla kendi alanlarına eleştirel yaklaşma, alanlarının öğretiminde farklı yöntemlerin olduğunun farkına varma olanağına sahip olurlar. Bu durum öğretmen adaylarının meslek yaşamında niteliklerinin artmasını sağlamaktadır. ÖÖYD kapsamında, konuların öğrenme ortamlarında öğrenciye nasıl ve ne şekilde aktarılacağı, hangi yöntem, teknik ve stratejilerin kullanılacağı ve kazanımlara uygun öğretim materyallerinin seçiminde nelere dikkat edilmesi gerektiği gibi konular kuramdan uygulamaya verilmektedir. Örneğin coğrafya öğretmeni adayının bir konunun (harita bilgisi, iklim bilgisi, nüfus ve yerleşme, çevre sorunları vb.) öğretiminde kullanılacak yöntem, teknik, araç-gereç seçimi, öğrenme ortamlarını düzenleme, değerlendirme, planlama, etkinlik hazırlama bilgi ve becerileri bu ders kapsamında edinmesi beklenir.

Öğretmenleri mesleğe hazırlama sürecinde önemli işlevi olan ÖÖYD, Cumhuriyet'in ilk yıllarından günümüze değin öğretmen eğitimi programlarında her zaman yerini almıştrr. Günümüzde ÖÖYD öğretmenlik programlarında ve "pedagojik formasyon" olarak nitelendirilen öğretmen yetiştirme programlarında yer almaktadır. Eğitim Fakülteleri Öğretmen Yetiştirme Lisans Programlarında (YÖK, 2007) "Öğretim ilke ve yöntemleri" (3 saat), "Özel öğretim Yöntemleri-l” (2-2 saat) ve "Özel öğretim yöntemleri-II" (2-2 saat) dersleri bu kapsamda verilmektedir. Bu ders grubundan "Öğretim ilke ve Yöntemleri" dersi tamamen teorik bir içeriğe sahiptir. "Özel Öğretim Yöntemleri-I" ve "Özel Öğretim Yöntemleri-II" ise teori ve uygulama içeriklidir. Sınıf öğretmenliği ile rehberlik ve psikolojik danışmanlık öğretmenliği programlarının dışındaki tüm öğretmenlik programlarında yer almaktadır (Çeliköz, 2016). Yenilenen Coğrafya Öğretmenliği Lisans Programı (2018) incelendiğinde, bu derslerin yerini "Öğretim illke ve Yöntemleri" (2 saat), "Coğrafya Öğrenme ve Öğretim Yaklaşımları" (2 saat), "Coğrafya Öğretimi 1" (3 saat) ve "Coğrafya Öğretimi 2" (3 saat) dersleri almıştır.

Eğitim anlayışının öğrenci merkezli bir yapıya dönüştüğü günümüzde ÖÖYD’nin önemi giderek arttğı ileri sürülebilir. Coğrafya öğretiminde de bu boşluğu doldurmak için son yıllarda bazı araştırmaların yapıldığı görülmektedir (Doğanay, 2014; Aydın ve Güngördü, 2015; Güngördü, 2001; Ünlü, 2014). Bu çalışmalarda öğretim ilke ve yöntemlerinin coğrafya dersine nasıl uygulanacağı üzerine tartışmalar yürütülmüştür. Alanyazında farklı alanlarda ÖÖYD'ye ilişkin araştırmaların yapıldığı da görülmektedir (Akpınar, Çolak ve Yiğit, 2012; Akyüz, Özcan ve Altıparmak, 2015; Çeliköz, 2016; Gülçiçek, 2018; Gürbüztürk ve Koç, 2016; Karamustafaoğlu ve Akdeniz, 2005; Yakar, Can ve Uçak, 2010; Karataş ve Cengiz, 2016). illgili çalışmalar incelediğinde, pedagojik formasyon eğitimi alan Coğrafya bölümü öğrencilerinin ÖÖYD’ye ilişkin görüşlerinin incelendiği herhangi bir çalışmaya rastlanmamıştr. Bu araştırma ile coğrafya öğretimimde dersi planlama, öğrenci öğrenmesine uygun eğitim durumları hazırlama, konu alanına uygun yöntem ve tekniklerini seçme ve dersin verimliliğini artırma üzerine öneriler sunularak alanyazına katkı sağlanacağı düşünülmektedir. Bu bağlamda mevcut çalışmanın amacı, formasyon eğitimi alan Coğrafya bölümü öğrencilerinin ÖÖYD’ye ilişkin görüşlerini belirlemek ve bu dersin etkililiğinin artırıması için öneriler ortaya koymaktır. Bu temel amaç doğrultusunda aşağıdaki sorulara cevap aranmıştır:

1. ÖÖYD’nin öğretmen adaylarının meslek yaşamına sağladığı katkılar nelerdir?

2. ÖÖYD'nin coğrafya öğretimindeki yerine ilişkin görüşler nelerdir?

3. ÖÖYD'de kuram ve uygulamaya ayrılan sürelere ilişkin görüşler nelerdir?

4. Öğrencilerin ÖÖYD almadan önceki beklentiler nelerdir?

5. ÖÖYD'nin daha etkin hale getirilmesi için neler yapılabilir? 


\section{Yöntem}

\section{Araştirma Modeli}

Bu nitel araştırma tipik durum çalışması olarak kurgulanmıştır. Tipik durum çalışmalarında gündelik hayatın bir parçası haline gelen durumlar belirlenmekte ve yorumlanmaktadır. Karmaşık olguların daha net bir biçimde ortaya konup anlaşılabilmesi için kullanılan nitel araştırma desenlerinden biri olan tipik durum, keşfedici ya da açıklayıcı-betimleyici nitelikte olabilmektedir (Yin, 2003). Bu çalışmada, pedagojik formasyon sertifika programına katılan coğrafya bölümü öğrencilerinin bu program kapsamında aldıkları özel öğretim yöntemleri dersine ilişkin görüşleri tipik bir durum olarak ele alınıp çözümlenmeye çalışımıştır.

\section{Katilımcilar}

Bu araştırmanın katılımcıları amaçlı örnekleme yöntemlerinden biri olan kolay ulaşılabilir örnekleme ile belirlenmiştir. Araştırma kapsamında 2016-2017 öğretim yılı güz yarıyılında Karabük Üniversitesi Edebiyat Fakültesi bünyesinde gerçekleştirilen pedagojik formasyon sertifika programına katılan ve ÖÖYD alan toplam 122 coğrafya bölümü öğrencisiyle görüşme yapılmıştr.

\section{Veri Toplama Araçları}

Araştırma verileri araştırmacılar tarafindan geliştirilen yarı yapılandırılmış bir görüşme formuyla toplanmıştır. Bu form, ilgili alan yazına ve uzman görüşlerine dayalı olarak araştırmacılar tarafindan geliştirilmiştir. Görüşme formunun kapsam geçerliği için 3 farklı alan uzmanının görüşlerine başvurulmuştur. Uzman görüşleri doğrultusunda forma son şekli verilmiştir. Formda genel olarak öğrencilerin özel öğretim yöntemleri dersine ilişkin görüşlerini belirlemeye dönük yedi soru bulunmaktadır. Görüşme formunda yer alan sorular aşağıda verilmiştir:

1. ÖÖYD'de edindiğiniz bilgi ve becerilerin meslek yaşamınıza katkıları olacağını düşünüyor musunuz? Düşünüyorsanız bunlar nelerdir? Açıklayınız.

2. ÖÖYD'nin Coğrafya öğretimindeki yeri sizce nedir?

3. Bu derslere ayrılan süre sizce yeterli midir? Nedenini açıklayınız.

4. ÖÖYD'nin işlenişinde kurama ve uygulamaya ayrılan süreleri nasıl değerlendirirsiniz? Size bu konuda bir seçenek sunulsa, kuram süresinin mi yoksa uygulama süresinin mi artırılmasını isterdiniz? Neden? Açıklayınız.

5. Bu ders sürecinde hangi konu/konuların üzerinde daha fazla durulması gerektiğini düşünüyorsunuz? Neden? Açıklayınız.

6. Bu dersleri almadan önceki beklentileriniz nelerdi? Dersleri aldıktan sonra hangi beklentilerinizin karşılandığını/ karşılanmadığını düşünüyorsunuz? Açıklayınız.

7. Etkili bir Coğrafya öğretiminin sağlanması için ÖÖYD'de geliştirilmesi gereken yönler nelerdir? ÖÖYD sizce nasıl düzenlenmelidir?

Araştırmanın gerçekleştirilmesi için gerekli yasal izinler alınmış, ardından öğrencilerle belirlenen yer ve tarihte yüz yüze görüşmeler yapılmıştrr. Görüşmelerin tamamlanması yaklaşık iki ay sürmüştür. Her bir görüşmeden önce araştrmanın amacı katılımcılara ayrıntılarıyla açıklanmış, görüşmelerin hangi amaçla kullanılacağı ve istendiği takdirde katlımcılarla araştırmanın bulgularının paylaşılabileceği belirtilmiştir. Görüşmeler ortalama 20 dakika sürmüş ve her bir görüşme ses cihazına kayıt edilmiştir.

\section{Verilerin Analizi}

Veriler içerik analiziyle çözümlenmiştir. Görüşme formunda yer alan sorulara verilen yanıtlar önce araştırmacıların her biri tarafindan benzerliklerine ve farklılıklarına göre kodlanmıştı. Daha sonra araştırmacıların ayrı ayrı oluşturduğu bu kodlar beraber incelenerek benzer olanlar netleştirilmiş, benzer olmayanlar üzerinde tartışılmış ve fikir birliğine varılarak ortak kodlar ve temalar oluşturulmuştur (Büyüköztürk vd., 2012). Uzman görüşlerine başvurularak bu kod ve temalara son hali verilmiştir. Oluşturulan bu kod ve temalar tablo halinde verilip frekans değerleri ile birlikte ve her bir koda ilişkin bir örnek katılımcı cevapları doğrudan alıntılar yapılarak sunulmuştur. Alıntılarda öğrenci (Ö: Numara) şeklinde kodlanmıştır.

Bu araştırmanın geçerliğini sağlamak için uzun süreli görüşme, katılımcı teyidi, ayrıntlı betimleme yaklaşımlarından yararlanılmıştır. Buna göre her bir katllımcıyla yapılan görüşmeler mümkün olduğunca uzun tutulmaya çalışımış ve 
araştırma problemi hakkından yeterince veri toplanana kadar veri toplama süreci devam ettirilmiştir. Her bir katılımcıyla yapılan ve ses kaydına alınan görüşmeler kağıda dökülmüş ve katılımcılarla paylaşılarak varsa eksikleri tamamlamaları istenmiştir. Son olarak araştırma süreci bir bütün olarak okuyucuya aktarılarak nitel araştirmalarda geçerliliğin önemli boyutlarından biri olan aktarılabilirlik sağlanmaya çalışılmıştır. Ayrıca araştırmanın güvenirliği sağlamak amacıyla araştırma süreci, nitel araştırmalar konusundan deneyimli bağımsız bir araştırmanın denetimi ve değerlendirmesine sunulmuştur.

\section{Bulgular}

Araştırmanın bu bölümünde, görüşlerine başvurulan pedagojik formasyon eğitimi almış Coğrafya bölümü öğrencilerinin ÖÖYD’ye ilişkin sorulara verdikleri yanıtlar sınıflandırılarak yorumlanmıştır.

Coğrafya bölümü öğrencilerinin ÖÖYD kapsamında edinilen bilgi ve becerilerin meslek yaşamlarına etkilerine ilişkin görüşleri Tablo 1'de yer almaktadır.

Tablo 1. ÖÖYD kapsamında edinilen bilgi ve becerilerin meslek yaşamlarına etkilerine ilişkin görüşler

\begin{tabular}{lc}
\hline Görüşler & f \\
\hline Katkısı olacağını düşünüyorum. & 118 \\
Katkısı olacağını düşünmüyorum. & 4 \\
\hline
\end{tabular}

Tablo 1'de görüleceği üzere, görüşlerine başvurulan Coğrafya bölümü öğrencilerinin tamamına yakını dersin uygulayıcısı olarak öğretmenlik yaşamlarında, ÖÖYD kapsamında edindikleri bilgi ve becerilerin katkısı olacağını düşünmektedirler. Yalnızca 4 katılımcı dersin meslek yaşamına katkısı olmayacağını ifade etmiştir.

Aşağıda çalışmaya katılan öğrencilerin bu soruya verdikleri cevaplardan bazı örnekler verilmiştir:

- Kesinlikle düşünüyorum çünkü bu derste aldığım bilgi ve uygulanan faaliyetleri ile hem kendi eksik yönlerimi hem de ilerdeki meslek durumdan dolayı çocukları eğitsel açıdan tamamlayacağımı düşünüyorum." (Ö3)

- "Katkısı olacaktır. Çünkü dersi hangi amaçla nasıl anlatacağımıza, hangi teknik ve yöntemin uygun olacağını, bilgileri karşımızdakine aktarırken öğrenci düzeyine aktarılacağını, verilmek istenen kazanım ve becerileri aktarmada önemli olacağını kesinlikle düşünüyorum" (Ö45)

- "Düşünüyorum çünkü bilgiyi bilmek yetmiyor... O bilgiyi öğrencilere etkili bir şekilde sunmak gerekiyor. Bu ders kapsamında bunları öğrendik. Faydalı olacaktır." (Ö60)

ÖÖYD’nin Coğrafya öğretimindeki yeri ve önemine ilişkin öğrenci görüşleri Tablo 2'de yer almaktadır.

Tablo 2. ÖÖYD’nin coğrafya öğretimindeki yeri ve önemine ilişkin öğrenci görüşler

\begin{tabular}{llc}
\hline Kategoriler & Kodlar & $\mathbf{f}$ \\
\hline \multirow{3}{*}{ Etkili öğretim } & Konuların açık ve anlaşılır öğretimi & 24 \\
& Eğlenceli & 12 \\
& Kolay ve kalıcı öğrenme & 8 \\
Yöntem belirleme & Farklı teknikleri öğrenme ve uygulama & 14 \\
Öğretmenlik mesleğine hazırlık & Anlatımı zenginleştirme & 13 \\
& Aktif öğrenme & 13 \\
\hline
\end{tabular}

Tablo 2'de görüldüğü gibi öğretmen adayları ÖÖYD'nin etkili öğretim, yöntem belirleme ve öğretmenlik mesleğine hazırlanma noktasında coğrafya eğitimine katkı sunacağını düşünmektedirler.

Aşağıda öğrencilerin bu soruya verdikleri cevaplardan bazı örnekler verilmiştir:

- “Çünkü bu ders boyunca öğrendiğimiz her türlü konu ve bilgi, meslek hayatımızda ve günlük hayatımızda kullanıyoruz." (Ö5)

- "Coğrafya öğretiminde hangi yöntemin kullanılması gerektiği konusunda..." (Ö75)

- "Öğrencilerimize Coğrafyayı sevdirmek, onları bu derse isteyerek hazırlamak ve öğretmek için öğretim yöntemle dersinin iyi bilinmesi ve iyi aktarılması gerektirmektedir." (Ö53)

- "Bu derste düz ve sıkıı anlatmakta ziyade Coğrafya dersini nasıl daha aktif daha eğlenceli daha bilgili katılımın fazla vb. ilgili teknik yöntemlerini ögretiyor." (Ö41) 
Coğrafya bölümü öğrencilerinin ÖÖYD’ye ayrılan süreye ilişkin görüşleri Tablo 3’te yer almaktadır.

Tablo 3. ÖÖYD’ye ayrılan süreye ilişkin görüşler

\begin{tabular}{cc}
\hline Görüşler & $\mathbf{n}$ \\
\hline Yeterli & 22 \\
Yetersiz & 71 \\
\hline
\end{tabular}

Tablo 3'e göre, araştrrmaya katılan öğrencilerin çoğunluğu $(n=71)$ derse ayrılan sürenin yetersiz olduğunu belirtmiştir. 22 öğrenci ise sürenin bu ders için yeterli olduğu görüşünü savunmuştur. Öğrencilerin bir kısmının ise konuya ilişkin yorum yapmadığını belirlenmiştir $(n=29)$.

Coğrafya bölümü öğrencilerinin ÖÖYD’nin işlenişinde kuram ve uygulamaya ayrılan süreye ilişkin görüşleri Tablo 4'te yer almaktadır.

Tablo 4. ÖöYD’nin işlenişinde kurama ve uygulamaya ayrılan süreye ilişkin görüşler

\begin{tabular}{cccc}
\hline \multicolumn{2}{c}{ Kuram } & \multicolumn{2}{c}{ Uygulama } \\
\hline Yeterli $(\mathbf{n})$ & Yetersiz $(\mathbf{n})$ & Yeterli $(\mathbf{n})$ & Yetersiz $(\mathbf{n})$ \\
\hline 115 & 7 & 7 & 115 \\
\hline
\end{tabular}

Tablo 4'de görüldüğü gibi, Coğrafya bölümü öğrencilerinin önemli bir kısmı $(n=115)$ dersin kurama ayrılan süresinin yeterli olduğunu düşünmektedir. Uygulama boyutu bağlamında bakıldığında ise öğrencilerin yine büyük bir kısmının ( $n$ = 115) dersin uygulama yapmaya ayrılan sürecinin yetersiz olduğunu düşündüğü anlaşımaktadır. Bu bulgu, öğrencilerin ÖÖYD'de kuram ve uygulama dengesinin kurulamadığını düşündüğünü göstermektedir.

Aşağıda öğrencilerin bu soruya verdikleri cevaplardan bazı örnekler verilmiştir:

- "Bu derste süre yeterli değildir çünkü uygulama gerektiren pekiştirme gerektiren bir ders olduğu için bu derste uygulamaların daha iyi pekiştirilmesi gerektiği için bu süre yeterli değildir." (Ö2)

- "Süre yetersizdir. Çünkü uygulama yaptığımız zaman dersin yarısı gidiyor geri kalan konular zaman kalmıyordu." (Ö95)

- " "Süre yeterliydi. Konu az olduğu için süre sıkıntısı yaşanmıyor." (Ö82)

- "Uygulama sürecini artrılması isterdim çünkü uygulamalar eğlenceli ve daha kalıcı bilgiler veriyor." (Ö32)

- "Ben uygulama süresinin artrılmasını isterim çünkü en iyi öğrenme şekli öğrencinin yaparak yaşayarak öğrenmesidir." (Ö67)

Coğrafya bölümü öğrencilerinin ÖÖYD kapsamında üzerinde daha çok durulması gerektiğini düşündükleri konulara ilişkin görüşleri Tablo 5'te yer almaktadır.

Tablo 5. ÖÖYD kapsamında üzerinde daha çok durulması gereken konulara ilişkin görüşler

\begin{tabular}{lll}
\hline Kategoriler & Kodlar & $\mathbf{f}$ \\
\hline & Öğrenci merkezli teknikler & 49 \\
Öğretim yöntem & Eğlenceli etkinlikler & 26 \\
ve teknikleri & Farklı̈ öretim uygulamaları & 16 \\
Sınıf hâkimiyeti & Öğrenci psikolojisi & 23 \\
& Sınıf kontrolü & 13 \\
Öğretim Programı & Program tanıtımı & 44 \\
& Kazanımlar & 12 \\
\hline
\end{tabular}

Tablo 5 incelendiğinde, Coğrafya bölümü öğrencilerinin ÖÖYD kapsamında üzerinde daha çok durulması gerektiğini düşündükleri konu öğretim yöntem ve teknikler ile bunların Coğrafya dersinde nasıl kullanılacağıdır. Ayrıca Coğrafya bölümü öğrencileri eğlenceli öğretim etkinliklerinin düzenlenmesinin, öğretim programının daha detaylı incelenmesinin, sınıf yönetimi ve öğrenci psikolojisinin dikkate alınması gerektiğini belirtmişlerdir.

Aşağıda öğrencilerin bu soruya verdikleri cevaplardan bazı örnekler verilmiştir:

- Dersi eğlenceli hale getirecek yöntemlerin yani eğlenerek etkili öğrenme yapılabilecek yöntemlerin üstünde daha fazla durulması daha uygundur. Ancak hepsine eşit vakit ayrıldığında bilinen yöntemlerde zaten herhangi 
bir sıkınt yokken yeni öğrenilen yöntemlerde kalıcı öğrenme sağlanamıyor." (Ö9)

- "Öğretim müfredatı ve hangi konuda hangi yöntem ve tekniğin uygun olduğu üzerinde durulmalı ve bu teknikler uygulaması yapılmalıdır." (Ö112)

- "Öğrenciyi eğlendiren altı şapka düşünme görüş geliştirme kartopu istasyon tekniği gibi konuların üzerinde daha durulabilir. Çünkü sınıf çoğunluğuna hitap eden farklı düşünceleri ortaya koyabilen konulardır." (Ö71)

Coğrafya bölümü öğrencilerine ÖÖYD almadan önceki beklentilerinin neler olduğu ve bu beklentilerinin karşılanıp karşılanmadığı sorusu yöneltilmiştir.

Tablo 6'da Coğrafya bölümü öğrencilerinin ÖÖYD'yi almadan önce dersten beklentilerinin neler olduğu sunulmuştur.

Tablo 6. Coğrafya bölümü öğrencilerinin ÖöYD almadan önce dersten beklentileri

\begin{tabular}{llc}
\hline Kategoriler & Kodlar & $\mathbf{f}$ \\
\hline Yöntem ve teknik öğrenme & Çağdaş öğretim yöntemleri & 30 \\
& Kuram ve uygulama & 15 \\
Coğrafya öğretimi & Eğlenerek öğrenme & 16 \\
& Olumlu tutum geliştirme & 12 \\
Öğretmenlik uygulaması & Mikro öğretim & 16 \\
& Örnek uygulamalar & 12 \\
Sınav başarısı & KPSS sınavı & 60 \\
Beklentinin olmaması & Bilgilerin olmaması & 40 \\
\hline
\end{tabular}

Tablo 6 incelendiğinde, kathlımcıların dersten önceki beklentilerinin çağdaş öğretim yöntemlerini öğrenme, coğrafya öğretimine yönelik olumlu bir turum geliştirme, KPSS sınavından başarılı olmak için gerekli bilgileri edinme noktasında yoğunlaştı̆ı görülmektedir. Bazı katılımcıların ise derse yönelik bilgileri olmadığından bir beklentilerinin de olmadığını belirtmişlerdir. Bununla birlikte derse yönelik beklentisi olan öğrencilerinin tamamı beklentilerinin karşılandığını ifade etmiştir. Örnek öğrenci görüşleri aşağıda verilmiştir:

- "Bu dersi almadan önce sınıfta nasıl ders anlatılması ve öğrenciyle nasıl iletişim kurulması konusunda bir fikrim yoktu daha sonra konuları kendi anlayacağım şekilde değil karşımdakinin anlayacağı bir şekilde anlatmayı ögrendim." (Ö3)

- "Pek işe yarayacağını düşünmemiştim ilk başta fakat dersleri işledikten sonra staja gittiğim zamanda gerçekten benim için verimli oldu şunu gördüm özellikle derste yapılan uygulamaların katkısı büyük oldu." (Ö19)

- "Açıç̧ası dersler olmadan önce bu derslerle ilgili pek bilgim olmadığından çok beklenti içerisinde değildim ama bu dersleri aldıktan sonra pek çok şeyi öğrendiğimi söyleyebilirim en azından öğrencilerin nasıl farklı düşüneceğini onlara neler sunabileceğimi edindiğimi düşünüyorum." (Ö48)

Coğrafya bölümü öğrencilerine etkili bir Coğrafya öğretiminin sağlanması için ÖÖYD’nin geliştirilmesi gereken yönlerin neler olduğu ve dersin nasıl düzenlenmesi gerektiği sorusu yöneltilmiştir. Katlımcıların görüşleri Tablo 7'de verilmiştir.

Tablo 7. ÖöYD’nin geliştirilmesi gereken yönlerine ilişkin katılımcı görüşleri

\begin{tabular}{llc}
\hline Kategoriler & Kodlar & $\mathbf{f}$ \\
\hline Öğretim teknolojileri & Çağdaş öğretim araç-gereçlerinin kullanımı & 25 \\
& Teknoloji kullanımı & 13 \\
Ders içeriği & Çağdaş ülkelerden örnek & 32 \\
& Uygulama örnekleri & 25 \\
Uygulama & Öğrenci merkezli & 21 \\
& Ders saati & 15 \\
\hline
\end{tabular}

Tablo 7’ye göre, öğrencilerin ÖÖYD’nin geliştirilmesi gereken yönleri bağlamında derslerde çağdaş öğretim araç-gereçlerinin kullanımına, ders içeriği kapsamında çağdaş ülkelerden farklı örneklerin sunulması gerektiğine ve daha öğrenci merkezli bir öğretim yapılması gerektiğine vurgu yaptıkları anlaşılmaktadır. Yine bazı öğrenciler bu dersin kapsamının yeniden gözden geçirilmesi gerektiğini ve bazı güncellemelere ihtiyaç duyulduğunu ifade etmişlerdir. Öğrenci görüşlerinden bazı örnekler aşağıda verilmiştir:

"Bana göre öğrenciye yönelik düzenlenmiş farklı ülkelerdeki yöntemlerden yararlanılarak dersin içeriğinde farklı düzenlemeler yapılmalıdır." (Ö1) 
"Daha çok uygulanabilir ve pratik yöntemlerle çünkü üretilen konuların birçoğu uygulamaya ne zaman nede öğrencinin ilgisinin yeteceğini düşünmüyorum." (Ö87)

"Kuramsal bilgilerim ilk 2 hafta kabataslak verilip kalan 12 hafta boyunca uygulama yaptrılarak öğretimi daha kalıcı olması sağlanmalıdır." (Ö65)

"Coğrafya görerek öğrenilen bir derstir bu ders kapsamında animasyonlar videolar üç boyutlu şekil ve görsellere ağırlık verilmesi özel öğretim yöntemlerinin geliştirilmesi gereken yönlerdir." (Ö109)

\section{Sonuç ve Tartışma}

Bu araştrrmada pedagojik formasyon eğitimi alan Coğrafya bölümü öğrencilerinin ÖÖYD’nin meslek yaşamına sağladığı katkılara ve coğrafya öğretimindeki yerine, ÖÖYD'de kuram ve uygulamaya ayrılan sürelere, bu dersi almadan önceki beklentilere ve ÖÖYD'nin daha etkili hale getirilmesi için yapılması gerekenlere ilişkin görüşleri ortaya konmuştur.

Bu çalışmada coğrafya bölümü öğrencilerinin tamamına yakınını ÖÖYD'de edindikleri bilgi ve becerilerin öğretmenlik yaşamlarında katkısı olacağını belirtmişlerdir. Çalışmaya katılan öğretmen adayları ÖöYD’nin Coğrafya öğretiminde önemli bir yeri olduğunu ve bu ders kapsamında öğrenilenlerle Coğrafya dersinin daha etkili ve eğlenceli hale gelebileceğini ifade etmişlerdir. Öne çıkan bir diğer sonuca göre, öğretmen adayları ÖÖYD’nin etkili öğretmen olma konusunda önemli ipuçları verdiğini belirtmiştir. Bu sonuç bu konuyla ilgili farklı alanlarda yapılan araştırma bulgularını desteklemektedir. Örneğin Eraslan (2009), Matematik öğretmeni adayları üzerine yaptı̆̆ı çalışmada ÖÖYD'nin öğretmenlerin mesleki yaşamlarını kolaylaştırdığını ortaya koymuştur. Gürbüztürk ve Koç'un (2016) araştırma bulguları ise öğretmen adaylarının dersin kendilerine alan bilgisi kazanma ve öğretim yöntem ve tekniklerini etkili bir biçimde kullanma konusunda yardımcı olduğunu belirttiklerini göstermektedir. Bu sonuç, ÖÖYD’nin öğretmenlerin hizmet öncesi eğitimi sürecinde önemini göstermektedir.

Araştırma sonuçları, öğretmen adaylarının dersin kurama yönelik bölümünün yeterli olduğunu ancak bu dersin daha etkili ve amaca uygun bir biçimde yürütülebilmesi için uygulama boyutuna ağırlık verilmesi gerektiğini düşündüklerini göstermektedir. Akyüz, Özcan ve Alttparmak (2015) tarafindan Türkçe öğretmeni adayları üzerine yapılan benzer bir çalışmada, öğretmen adayları derslere ayrılan sürenin genel olarak yeterli olduğunu; ancak uygulamaya ayrılan sürenin daha fazla olması gerektiğini vurgulamaktadır. Öğretmen adayları uygulama süresinin fazla olmasının pekiştirmeyi ve dönütlerin daha etkili olmasını sağlayabileceğini belirtmişlerdir. Derste yapılan uygulamaların sayısının artırılması önerisi Akpınar, Çolak ve Yiğit'in (2012) Öğretmenlik Uygulaması dersi kapsamında yaptıkları araştırma sonuçları ile de örtüşmektedir.

Bu çalışmada öne çıkan bir diğer sonuca göre, öğretmen adaylarının ders kapsamında etkili öğretim yöntem ve tekniklerini Coğrafya dersinde nasıl kullanılacakları üzerinde daha çok durulması gerektiğini belirtmişlerdir. Buna göre pedagojik formasyon sertifika programına katılan coğrafya bölümü öğrencileri ÖÖYD’yi, alan bilgisinin etkili biçimde sunulmasını öğrenmeye yönelik bir ders olarak görmektedir. Coğrafya konuları içerisinde birçok soyut kavram yer almaktadır. Bu kavramlar öğrencilere etkili öğretim yöntemleri kullanılarak somuttan soyuta, yakından uzağa, bilinenden bilinmeyene gibi öğretim ilkeleri dikkate alınarak verilmelidir. Bu bağlamda ÖÖYD kapsamında teorik bilgilerden daha çok pratik bilgilerin yani sınıfta uygulama biçimlerinin verilmesinin daha uygun olduğu anlaşılmaktadır.

Bilindiği gibi Pedagojik Formasyon Sertifika Programlarında öğretim yöntemleri üzerine dersler verilmektedir (ör. Öğretim illke ve Yöntemleri). Ancak ÖÖYD'de ilgili alana özgü sınıf içi uygulamalar yapılmaktadır. Coğrafya öğretiminde de özellikle sınıf ortamında uygulanabilecek birçok öğretim yöntem ve tekniği bulunmaktadır (Doğanay, 2014; Aydın ve Güngördü, 2015; Ünlü, 2015). Volkanların oluşumunda "Deney Yöntemi", Göç konusunun öğretiminde "istasyon" tekniği, Türkiye'de görülen iklim tipleri konusunda "İşbirlikli Öğrenme", Enerji Kaynakları konusunda "Altı şapka düşünme tekniği", Akarsuların oluşturduğu yeryüzü şekillerinin öğretiminde "Kavram Haritaları" bunlar arasında sayılabilir. Ancak ÖÖYD'de bunların örnek uygulamalarının yapılabilmesi için daha fazla süreye ihtiyaç olduğu bu araştırma sonucunda ortaya konmuştur.

Türkiye'de coğrafya öğretimde karşılaşılan önemli sorunlardan biri, yenilenen müfredat değişikliğine rağmen, öğretimin hâlâ öğretmen merkezli yöntem, teknik ve stratejilerle sürdürülmesidir. Günümüz eğitim anlayışı artık öğretmen merkezli değil, yaparak ve yaşayarak öğrenmenin gerçekleştiği, öğrencilerin konuları günlük yaşamla ilişkilendirdiği, öğretmenin dersi hazırlayıp sunan değil, öğrenciye yol gösterici olduğu, kısaca öğrenci merkezli bir anlayışa dönüşmüştür (Aydın, 2012). Bu noktada öğrencilerin etkin bir biçimde derslere katılmalarının sağlandığı yapılandırmacı yaklaşımı dikkate alan öğretim yöntemleriyle (Proje tabanlı öğrenme, probleme dayalı öğrenme, aktif öğrenme, çoklu zeka vb.) yapılan coğrafya öğretimi ile öğrencilerin başarıları, tutumları ve derse olan ilgilerinin arttğı not edilmelidir (Demirkaya,

| Kastamonu Eğitim Dergisi, 27(5), 2019| 
2003; Coşkun, 2004; Çepni ve Aydın, 2015; Aksoy, 2004; Akşit, 2007; Alaz, 2007; Öner ve Aydın, 2014; Ceylan, 2017; Özüpekçe, 2014 ).

Çalışmada öne çıkan bir diğer sonuca göre Coğrafya bölümü öğrencileri ÖÖYD kapsamında öğretim programının daha detaylı bir biçimde incelenmesi gerektiğini belirtmişlerdir. Bilindiği üzere ders içerisinde yapılan tüm etkinlikler öğretim programı ve kazanımlar dikkate alınarak hazırlanmaktadır. Bu kapsamda Coğrafya öğretmen adaylarına programın amacı, temel beceriler, coğrafi beceriler, öğretim programının uygulanmasında dikkat edilmesi gereken hususlar, programın yapısı, sınıf düzeyine göre ünite ve kazanımlar hakkında yeterli bilgi verilmesi gerekmektedir.

Bu araştırmanın bir diğer sonucuna göre, öğretmen adayları ÖÖYD'de sınıf yönetimi üzerine daha fazla durulması gerektiğini belirtmişlerdir. Sınıf yönetimi, sınıfta öğrenme için uygun ortamın sağlanması ve sürdürülmesine göndermede bulunmaktadır. Bunu sağlayabilmek için öğretmenin sınıf içi etkinlikleri ve öğrenme-öğretme süreçlerini planlaması gerekmektedir. ÖÖYD kapsamında etkinlikler planlanırken öğrencilerin ders içinde dikkatini çekecek, motivasyonunu ve derse katılımını arttıracak sınıf yönetimi stratejileri dikkate alınmalıdır.

\section{5. Öneriler}

Araştırma bulgularından yola çıkarak şu önerilerde bulunulabilir:

- Katılımcılardan alınan görüşler doğrultusunda, bu dersleri veren öğretim elemanlarının dersin başında öğrencileri içeriğe yönelik bilgilendirmesi ve onların derse yönelik hazır bulunuşluğunu artırması gerektiği söylenebilir.

- ÖÖYD'ye ayrılan sürenin kuram ve uygulama boyutu yeniden düzenlenmeli, uygulamaya ayrılan süre artrilmalıdır.

- ÖÖYD'de sınıf yönetimi ve öğretim programları üzerinde daha fazla durulmalıdır.

- Buna benzer araştırmalar daha geniş bir örneklem üzerinde gerçekleştirilebilir. Çalışma grubunun genişletilmesi; ÖÖYD'yi yürüten akademisyenlere daha sağııklı dönüt sunulması ve derslerin daha etkili bir biçimde sürdürülmesi açısından yararlı olabilir.

\section{Kaynakça}

Akpınar, M., Çolak, K. ve Yiğit, E. (2012). Öğretmenlik uygulaması dersi kapsamında sosyal bilgiler öğretmen adaylarının yeterliklerine yönelik uygulama öğretmenlerinin görüşleri. M.Ü. Atatürk Eğitim Fakültesi Eğitim Bilimleri Dergisi, 36, 41-67.

Aksoy, B. (2004). Coğrafya Öğretiminde Probleme Dayalı Öğrenme. Yayımlanmamış Doktora Tezi, Gazi Üniversitesi Eğitim Bilimleri Enstitüsü, Ankara.

Akşit, F. (2007). Coğrafya Öğretiminde Aktif Öğrenmenin Akademik Başarı ve Tutum Üzerine Etkisi. Yayınlanmamış Doktora Tezi, Gazi Üniversitesi, Eğitim Bilimleri Enstitüsü, Ankara.

Akyüz, E., Özcan, Ş. ve Alttparmak H.M. (2015). Türkçe öğretmen adaylarının Türkçe Özel Öğretim Yöntemleri dersine ilişkin görüşleri. Dil Eğitimi ve Araştırmaları Dergisi, 1(1), 65-76.

Alaz, A. (2007). Coğrafya Öğretiminde Çoklu Zekô Uygulamaları. Yayımlanmamış Doktora Tezi, Gazi Üniversitesi Eğitim Bilimleri Enstitüsü, Ankara.

Aydın, F. (2012). Sosyal Bilimler Lisesi Öğrencilerinin Coğrafya Dersinin Öğretimine Yönelik Görüşleri. Kastamonu Eğitim Dergisi, 20(3), 1035-1050.

Aydın, F. ve Güngördü, E. (2015). Coğrafya eğitiminde özel öğretim yöntemleri. Ankara: Pegem Akademi.

Büyüköztürk, Ş., Kılıç-Çakmak, E., Akgün, Ö. E., Karadeniz, S. ve Demirel, F. (2012). Bilimsel araştırma yöntemleri. (11. Baskı). Ankara: Pegem Akademi.

Calp, M. (2005). Özel öğretim alanı olarak Türkçe öğretimi. Konya: Eğitim kitabevi.

Ceylan, D. (2017). Coğrafya eğitiminde 5E modeliyle uygulanan bağlam temelli öğretim yaklaşımının akademik başarıya etkisi. Yayımlanmamış Doktora Tezi, Gazi Üniversitesi Eğitim Bilimleri Enstitüsü, Ankara.

Coşkun, M. (2004). Coğrafya Eğitiminde Proje Tabanlı Öğrenme Yaklaşımı. Yayımlanmamış Doktora Tezi, Gazi Üniversitesi Eğitim Bilimleri Enstitüsü, Ankara.

Çeliköz, M. (2016). Öğretmen adaylarına yönelik Özel Öğretim Yöntemleri I dersi tutum ölçeği geçerlilik güvenirlik çalışması. International Online Journal of Educational Sciences, 8 (3), 252-271.

Çepni, O. \& Aydın, F. (2015). Coğrafya Öğretmen Adaylarının Öğretmenlik Uygulaması Dersi Kapsamında Karşılaşı̆ı̆ı Sorunlar ve Çözüm Önerileri. Türkiye Sosyal Araşttrmalar Dergisi, 19(2), 285-304. 
Demirkaya, H. (2003). Coğrafya Öğretiminde 4MAT Öğretim Sisteminin Lise Coğrafya Derslerindeki Başarı ve Tutumlar Üzerine Etkisi. Yayımlanmamış Doktora Tezi, Gazi Üniversitesi Eğitim Bilimleri Enstitüsü, Ankara.

Doğanay, H. (2014). Coğrafya öğretim yöntemleri (Liselerde coğrafya eğitim ve öğretimi). Ankara: Pegem Akademi.

Eraslan, A. (2009) ilköğretim matematik öğretmen adaylarının 'öğretmenlik uygulaması' üzerine görüşleri. Necatibey Eğitim Fakültesi Elektronik Fen ve Matematik Eğitimi Dergisi (EFMED), 3(1), 207-221.

Gülçiçek, D. (2018). Türkçe öğretmenliği lisans programındaki Özel Öğretim Yöntemleri I-Il derslerinin değerlendirilmesi. Yayımlanmamış Doktora Tezi. Ankara Üniversitesi Eğitim Bilimleri Enstitüsü, Ankara.

Güngördü, E. (2001). Coğrafya'da öğretim yöntemleri, ilkeler ve uygulamalar. Ankara: Nobel Yayın Dağıtım Ltd. Şti.

Gürbüztürk, O. ve Koç, A. (2016). "Özel Öğretim Yöntemleri” dersinin yürütülmesine ilişkin öğretim elemanı ve öğretmen adaylarının görüşleri. Uluslararası Eğitim Programları ve Öğretim Çalışmaları Dergisi, 6(12), 57-79.

Karamustafaoğlu, O. ve Akdeniz A. R. (2005). Özel Öğretim Yöntemleri uygulamalarında fizik öğretmen adaylarının gerçekleştirdikleri etkinliklerin değerlendirilmesi. Eurasian Journal of Educational Research, 18, 128-141.

Karataş, F. Ö. ve Cengiz, C. (2016). Özel Öğretim Yöntemleri II dersinde gerçekleştirilen mikro-öğretim uygulamalarının Kimya öğretmen adayları tarafından değerlendirilmesi. Kastamonu Eğitim Dergisi, 24(2), 565-584.

Öner, S. ve Aydın, F. (2014). The Effects of Geography Information Systems Supported Training on the Academic Success in Geography Course. Türkiye Sosyal Araştirmalar Dergisi, 18(3),179-196.

Özüpekçe, S. (2014). Ortaöğretim lise 1. sınıf coğrafya derslerinde bilgisayar destekli coğrafya öğretiminin öğrencilerin coğrafya dersine karşı tutum, başarı ve hatırda tutma düzeyine etkisi. Yayımlanmamış Doktora Tezi, Dokuz Eylül Üniversitesi Eğitim Bilimleri Enstitüsü, İzmir.

Ünlü, M. (2014). Coğrafya öğretimi. Ankara:Pegem Akademi.

Yakar, Z., Can B. T. ve Uçak E. (2010). Özel Öğretim Yöntemleri dersinin fen öğretmen adaylarının fen öğretme felsefelerine etkisi. E-Journal of New World Sciences Academy, 5(4), 1469-1483.

Yin, R. K. (2003). Case study research: Design and methods (3rd Ed.). Thousand Oaks, CA: Sage

Yükseköğretim Kurulu (YÖK). (2007). Eğitim fakültesi öğretmen yetiştirme lisans programları. Ankara: Yükseköğretim Kurulu. 